\title{
Evaluation of feeding supply and forage cactus processing for lactation cows
}

\section{Márcio da Silva Vilela ${ }^{1}$, Marcelo de Andrade Ferreira ${ }^{2 *}$, Marcílio de Azevedo ${ }^{2}$, Iderval Farias $^{3}$, Luiz Carlos Leal Torres ${ }^{2}$, Amanda Vasconcelos Guimarães ${ }^{4}$}

1 Instituto Federal do Maranhão - Campus São Raimundo das Mangabeiras - MA - Brasil.

2 Universidade Federal Rural de Pernambuco - Departamento de Zootecnia, Av. Dom Manoel de Medeiros, S/N, Dois Irmãos, 52171-900 Recife, $P E$, Brasil.

${ }^{3}$ Instituto Agronômico de Pernambuco, PE, Brasil.

${ }^{4}$ Doutoranda - UFLA - MG - Brasil.

* Pesquisador CNPq.

ABSTRACT - The aim of this study was to evaluate the effect of the manner in which diet is supplied and spineless cactus forage is processed on intake, nutrient digestibility, milk production and composition, concentration of plasma urea nitrogen (PUN) in the milk urea nitrogen (MUN) and production of microbial protein in Holstein cows in lactation. Eight cows (453 $\pm 75.8 \mathrm{~kg}$ ) yielding $14 \mathrm{~kg}$ milk/day were allotted to a factorial design, with two manners of cactus processing (knifechopped or forage machine) and two diet supplies (separate concentrate or total mixed ration). Intakes of dry matter, organic matter, neutral detergent fiber and total digestible nutrients were lower when cactus was knife-chopped. Digestibility, milk production and fat and protein yield did not change according to the manner diet was supplied neither by forage cactus processing. Average milk production was $14.8 \mathrm{~kg} /$ day for knife-chopped cactus and $14.6 \mathrm{~kg} / \mathrm{day}$ for cactus chopped in forage machine and $14.8 \mathrm{~kg} /$ day when cactus was given in separate concentrate and $14.5 \mathrm{~kg} /$ day when it was given in total mixed ration. However, fat content was lower (36 g/kg) for knife-chopped cactus fed cows. Purine derivatives and concentrations of $\mathrm{N}$-ureic were not influenced by the manner in which diet was supplied neither by the forage cactus processing. Means observed for efficiency of microbial protein synthesis (98.9 g/kg TDN), PUN concentrations (21.3 mg/dL) and MUN (18.2 mg/dL) were similar for cactus processing and for the manner in which diet was supplied. Forage-machine cactus processing improves dry matter intake and total mixed ration supply avoids selectivity.

Key Words: milk production and composition, Opuntia fícus indica Mill, purine derivatives, semi-arid, total mixed ration

\section{Avaliação da forma de fornecimento da dieta e do processamento da palma- forrageira para vacas em lactação}

RESUMO - Objetivou-se avaliar o efeito da forma de fornecimento da dieta e do processamento da palma forrageira sobre o consumo, a digestibilidade dos nutrientes, a produção e a composição do leite, a concentração de N-ureico no plasma (NUP) e no leite (NUL) e a produção de proteína microbiana em vacas holandesas em lactação. Foram utilizadas oito vacas com $453 \pm 75,8 \mathrm{~kg}$ e produção de $14 \mathrm{~kg}$ de leite/dia distribuídas em arranjo fatorial, com duas formas de processamento do cacto (picado a faca ou em máquina forrageira) e duas formas de fornecimento da dieta (concentrado separado e mistura completa). Os consumos de matéria seca, matéria orgânica, fibra em detergente neutro e nutrientes digestíveis totais foram menores quando o cacto foi processado a faca. A digestibilidade, a produção de leite e as produções de proteína e gordura não foram alteradas pela forma de fornecimento da dieta nem pelo processamento da palma-forrageira. A produção média de leite foi de 14,8 kg/dia para a palma picada a faca e de 14,6 kg/dia para a palma picada em máquina forrageira e de 14,8 kg/dia quando fornecida em concentrado separado e de $14,5 \mathrm{~kg} / \mathrm{dia}$ quando em mistura completa. Todavia, o teor de gordura foi menor (36 g/kg) para nas vacas alimentadas com a palma picada a faca. Os derivados de purina e as concentrações de N-ureico não foram influenciados pela forma de fornecimento da dieta nem pelo processamento da palma-forrageira. As médias observadas para eficiência da síntese de proteína microbiana (98,9 g/kg NDT), concentrações de NUP (21,3 mg/dL) e NUL (18,2 mg/dL) foram semelhantes para o processamento do cacto e a forma de fornecimento da dieta. O processamento da palma em máquina forrageira melhora o consumo de matéria seca e o fornecimento em forma mistura completa evita a seletividade.

Palavras-chave: derivados de purina, mistura completa, Opuntia fícus indica Mill, produção e composição do leite, semiárido

Received May 26, 2009 and accepted May 14, 2010

Corresponding author: vilelamarcio@ifma.edu.br 


\section{Introduction}

The semi-arid region in northeastern Brazil is characterized by scarce, irregular, poorly distributed rainfall and high temperatures. The low nutritive value of the forage from this region is the main obstacle to increasing animal productivity in the region, which concentrates a population of dairy cattle (Dubeux Jr. et al., 2006).

Producers have used feed components adapted to the region as a forage alternative. Therefore spineless cactus (Opuntia fícus indica Mill) has been widely used for dairy cattle in Brazilian northeastern semi-arid, traditionally knife chopped provided to increase consumption and to avoid waste. However, handling requires much labor, mainly to larger quantities of the palm, and also because it is a common habit of the producers to provide separately the diet ingredients .

Spineless cactus is known for its remarkable physiological adaptation to water shortage and for its tolerance to dry weather conditions. Its most outstanding feature is the enormous potential for the production of large quantity of green and juicy forage, even under relatively unfavorable conditions (Nobel, 2001). Besides, spineless cactus also has considerable palatability, high content of mucilage and moisture, which can be a source of drinking water for animals (Ben Salem et al., 2002).

The use of total mixed ration (TMR) has been used as a way to regulate diet composition for high production animals (Van Soest, 1994), as well as to contribute to diet supply that, theoretically, must provide all the nutrients balanced, making it possible to feed a large number of animals with a homogeneous diet. Contrarily, in some feed systems, the concentrated food is individually offered in one or more portions per day. In this case, possible abrupt changes in the ruminant environment lead to the occurrence of digestive disorders (Nocek, 1997). In that sense, according to the NRC (2001), when the ingredients are consumed in TMR, ruminant fermentation is more uniform and there is a better use of nutrients than when the feed is supplied with separate ingredients.

It is expected that the assessment of feeding strategy and spineless cactus processing may influence the selectivity of the diet and the productive performance of lactating cows.

The aim of the present study was to assess the effect of feeding strategy and processing of spineless cactus on the intake and digestibility of different nutrients, milk production and composition, microbial protein production and N-urea excretion in lactating Holstein cows.

\section{Material and Methods}

The experiment was conducted at the Estação Experimental - São Bento do Una, which belongs to Instituto Agronômico de Pernambuco - IPA, Pernambuco, Brazil, from January to March 2007. The average precipitation of the region is $601.6 \mathrm{~mm}$ per year, and it is concentrated from March to July, which approximately corresponds to $60 \%$ of the total annual volume. The highest temperatures $\left(>30^{\circ} \mathrm{C}\right)$ are observed from November to January. Monthly average temperature varies from $21.0^{\circ}$ to $24.6^{\circ} \mathrm{C}$, with annual average temperature of $23.0^{\circ} \mathrm{C}$. Air relative humidity is $66 \%$ on average (FIDEPE, 1982).

Eight lactating Holstein cows with average body weight of $453 \pm 75.8 \mathrm{~kg}$, and milk production of $14 \mathrm{~kg}$ /day were used. Out of these eight cows, four were primiparous at \pm 3 years of age and four were multiparous at the fourth lactation at \pm 7 years of age. Cows started the experiment with 24 weeks of lactation, they were housed in individual pens made of barbed wire and beat dirt floor, with a covered area of $6 \mathrm{~m}^{2}$, equipped with trough for feed supply and water trough for ad libitum supply of water. For the hottest hours of the day (from 10:00 a.m. to 4:00 p.m.), the animals were placed in a masonry shed (where milking was done) covered with ceramic tile roof.

Feed was ad libitum supplied twice a day, at 7:00 a.m. (50\%) and at 4:00 p.m. (50\%), with all the ingredients provided in the same time. The experimental diet (Table 1) was made up of spineless cactus (Opuntia fícus indica Mill cv. Gigante) (47.3\%), sugarcane bagasse (32.4\%), soybean meal (18.8\%) and mineral mixture (1.5\%) based on dry matter. The cactus cladodes were daily collected, from the second two-year cladode. Later, they were stored in shaded area, immediately before the feeding, for their improvement. Sugarcane bagasse was added to the diet despite its low palatability because it is widely used in daily cattle farming in Pernambuco state during forage shortage periods. Food intake was calculated by the difference from the supplied ingredients and the leftover. It was used a $4 \times 4$ latin square design with two simultaneous squares based on lactation order of the cows (primiparous and multiparous). Four 15-day periods were used - ten days for the adaptation of the animals to the forms of diet and cactus processing and five for data collection. Treatments were distributed in factorial arrangement with two forms of cactus processing: knife chopped in which cactus were cut in bigger dimension pieces $(12 \times 5 \mathrm{~cm})$, or they were processed using Sertaneja Master Model (Nogueira ${ }^{\circledR}$ )forage machine, with about 2-cm cuts to expose the mucilage; and two feeding strategies: 
separate concentrate in which the trough was divided into two parts with concentrate put in one side, and the remaining ingredients in the other, all at the same time and total mixed ration (TMR). The ingredients were mixed with fork fodder in the trough at the moment when feed was being given.

Two milkings were performed every day, at 5:00 a.m. and at 3:00 p.m., and the individual production of each animal was recorded throughout the experimental period. Milk samples were collected on the $12^{\text {th }}$ day of each period, during morning and afternoon milkings, and composed samples were made to determinate protein and fat contents proportional to morning and afternoon productions $(40 \mathrm{~mL})$.

For the determination of urea and purine derivative (allantoin), milk was deproteinized using trichloroacetic acid (10 mL of milk $+5 \mathrm{~mL}$ of the acid at $25 \%$ ), filtered through paper filter and then stored at $-20^{\circ} \mathrm{C}$. The analyses of milk composition were performed by infrared absorption using the equipment Bentley 2000 (Bentley Instruments ${ }^{\circledR}$ ) in Laboratório de Qualidade do Leite e Nutrição Animal do Departamento de Zootecnia da Universidade Federal Rural de Pernambuco- Brazil. During collection period, urine "spot" sample (single collection) was obtained on the $13^{\text {th }}$ day of each experimental period, approximately four hours after feeding, during spontaneous urination. The sample was homogenized, filtered(Valadares et al., 1999), and a 10-mL sample was removed and diluted in $40 \mathrm{~mL}$ sulfuric acid $(0.036 \mathrm{~N})$. After that, $\mathrm{pH}$ was determined and adjusted to $<3$ and the sample was stored at $-20^{\circ} \mathrm{C}$ for further purine derivatives analyses. Total excretion of the purine derivatives in the urine (mmol/day) was estimated by the sum of uric acid and allantoin. The endogenous excretion of PD was assumed a constant of $0.385 \mathrm{LW}^{0.75}$ (Chen \& Gomes, 1992).
Absorbed purines (X, mmol/day) were calculated from the excretion of purine derivatives ( $\mathrm{Y}, \mathrm{mmol} /$ day) based on the following equation: $\mathrm{X}=\left\{\mathrm{Y}-\left(0.385 \times \mathrm{LW}^{0.75}\right)\right\} / 0.85$, in which 0.85 is the recovery of absorbed purines (such as purine derivatives) and $0.385 \mathrm{LW}^{0.75}$ is the endogenous contribution for purine excretion (Verbic et al., 1990). Ruminal synthesis of nitrogen ( $\mathrm{Y}, \mathrm{gN} /$ day) was estimated from the absorbed purines (X, mmol/day) based on a modification of the equation described by Chen \& Gomes (1992), in which the N-purine: N-total ratio of 0.116 was changed to 0.134 in bacteria, according to Valadares et al. (1999). The resulting equation was: $\mathrm{Y}=70 \mathrm{X} / 0.83 \times 0.134 \times 1000$, in which 70 is the $\mathrm{N}$ content in purines (mg N/mol); 0.134 is the $\mathrm{N}$-purine: $\mathrm{N}$-total ratio of the bacteria; and 0.83 is the digestibility of microbial purines. The efficiency of the nitrogen microbial synthesis (EmicSN) was calculated by the amount of micN synthesized by the intake of organic matter apparently digested in the rumen $(\mathrm{IOMDR})$. EmicSN (g/kg) = micSN (g)/IOMDR $(\mathrm{kg})$, in which IOMDR = IOM $\times$ ADOM $\times 0.65$ (ARC, 1980); $\mathrm{IOM}=$ intake of digestible organic matter; and ADOM = apparent digestibility of organic matter. The estimated microbial crude protein (MP) was obtained by multiplying micSN by 6.25 . The synthesis efficiency was calculated using the following formula: MP (g/kg) = MP (g)/ ITDN (kg), in which MP = microbial protein and ITDN = intake of total digestive nutrients.

Total carbohydrates (TCH) contents were calculated according to the equation proposed by Sniffen et al. (1992): $\% \mathrm{TCH}=100-(\% \mathrm{CP}+\%$ ether extract $+\%$ ash $)$. The nonfibrous carbohydrates (NFC) estimate was calculated using the difference between \%TCH and \%NDF.

For calculating the total digestible nutrients (TDN), the equation proposed by Weiss (1999) was used: TDN $=(D C P$ + DNFC + DNDF + $(\mathrm{DEE} \times 2.25))$, in which DCP = digestible

Table 1 - Chemical composition of ingredients and experimental diet

\begin{tabular}{|c|c|c|c|c|}
\hline & \multicolumn{3}{|c|}{ Feed } & \multirow{2}{*}{$\begin{array}{c}\text { Diet } \\
\text { composition }\end{array}$} \\
\hline & Soybean meal & Spineless cactus & Sugar cane bagasse & \\
\hline Dry matter (\%) & 88.9 & 9.2 & 66.5 & 42.6 \\
\hline Crude protein (\% DM) & 52.5 & 4.4 & 1.4 & 12.4 \\
\hline Ether extract (\% DM) & 3.2 & 2.3 & 0.9 & 2.0 \\
\hline Total carbohydrates (\% DM) & 35.8 & 82.9 & 93.4 & 76.2 \\
\hline Non-fibrous carbohydrates (\% DM) & 22.9 & 51.4 & 9.7 & 31.8 \\
\hline Neutral detergent fiber (\% DM) & 13.0 & 31.4 & 83.7 & 44.4 \\
\hline NDFcp $^{1}$ (\% $\quad$ DM) & 9.9 & 30.2 & 80.1 & 42.1 \\
\hline Acid detergent fiber (\% DM) & 6.1 & 15.5 & 60.5 & 28.1 \\
\hline Lignin (\% DM) & 0.3 & 3.2 & 11.9 & 5.4 \\
\hline NDIP $^{2}$ (\% $\%$ DM) & 5.3 & 26.7 & 78.1 & 38.9 \\
\hline $\mathrm{ADIP}^{2}$ (\% DM) & 0.6 & 11.3 & 65.1 & 26.5 \\
\hline Ash (\% DM) & 6.4 & 9.6 & 3.2 & 8.3 \\
\hline Total digestible nutrients 3 & 84.1 & 68.6 & 41.1 & 61.6 \\
\hline
\end{tabular}

${ }^{1}$ Neutral detergent fiber corrected to ash and protein (NDFcp).

${ }^{2}$ NDIP $=$ Neutral detergent insoluble protein (NDIP), ADIP = acid detergent insoluble protein (ADIP).

${ }^{3}$ Estimated by NRC (2001). 
crude protein, DNFC = digestible non-fibrous carbohydrates, DNDF = digestible neutral detergent fiber and DEE = digestible ether extract.

For determination of apparent digestibility of the nutrients, the production of dry fecal matter was estimated using LIPE ${ }^{\circledR}$ (modified and enriched hydroxyphenylpropane - purified eucalyptus lignin) as the external indicator. It was daily administered at 6:00 a.m. in a single dose capsule (500 mg/animal/day) for a six-day period (two days during the adaptation period, and four during the collection period). The feces samples were directly obtained in the rectal ampoule in days 1, 2, 3 and 4 of the collection period, at 6:00 a.m., 9:00 a.m., 12:00 p.m. and 3:00 p.m., respectively, each day, and then they were duly packed in labeled plastic bags. Four samples were collected per animal per period and at the end of the experiment, it was performed one composite sample of each treatment. The samples were subsequently dried at $65^{\circ} \mathrm{C}$ for 72 hours in a forced ventilation oven, ground into $1 \mathrm{~mm}$ and analyzed at the Laboratório de Nutrição Animal do Departamento de Zootecnia da Escola de Veterinária da UFMG-Brazil using a spectrophotometer, model Varian 099-2243 (Saliba, 2005) with a light detector in the infrared spectrum (FTIR). Fecal production with LIPE was calculated from the logarithmic rate of the absorption intensities in the samples, in wave length ranges from 1050 to 1650 , according to Saliba (2005):

Fecal production $(\mathrm{kg} / \mathrm{d})=\underline{\text { Dose of the supplied indicator }}$ Ai $\times 100 /$ fecal DM

in which, $A=$ logarithmic rate of the absorption intensities at 1050 and $1650 \mathrm{~nm} ; \mathrm{A}_{\mathrm{i}}=\mathrm{A}_{1050} / \mathrm{A}_{1650} ; \mathrm{A}_{1050}=\log \left(\mathrm{I}_{\mathrm{o}} / \mathrm{I}\right)$; $\mathrm{A}_{1650}=\log \left(\mathrm{I}_{\mathrm{o}} / \mathrm{I}\right) ; \mathrm{I}_{\mathrm{o}}=$ the highest absorption intensity of the sample; $\mathrm{I}=$ the lowest absorption intensity of the sample.

After the collection period, all samples were oven dried at $65^{\circ} \mathrm{C}$ for $72 \mathrm{~h}$, grounded using a Wiley Mill with a $1 \mathrm{~mm}$ screen and stored for further analyses of dry matter (DM), crude protein (CP), ether extract (EE) and ash, according to the methodology described by Silva \& Queiroz (2002).

Feed samples were analyzed for neutral detergent fiber (NDF) and acid detergent fiber (ADF) with methodology described by Van Soest et al. (1991), using nylon bags (TNT) with ANKON bag similar measures. For determination of neutral detergent fiber of the feeds (soybean meal and cactus), it was used $8 \mathrm{~mol}$ solution of alpha-amylase and urea. Neutral detergent fiber of the feed was corrected for ash and protein, resulting in an ash-and-protein-free NDF (NDFcp).

The content of neutral detergent insoluble crude protein (NDICP) and acid detergent insoluble crude protein (ADICP) of the food were estimated from the residuals from the extraction of neutral and acid detergents, respectively, from the samples (Licitra et al., 1996), using the procedure described by Kjeldahl. For lignin determination (lignin determined by cellulose solubilization with sulphuric acid), it was used the method described by Van Soest (1967), using sulfuric acid $\left(\mathrm{H}_{2} \mathrm{SO}_{4}\right)$ at $72 \%$.

Statistical analysis was performed using the following mathematical model:

$\mathrm{Y}_{\mathrm{ijklm}}=\mu+\mathrm{P}_{\mathrm{i}}+\mathrm{Q}_{\mathrm{j}}+\mathrm{A}_{\mathrm{k}}+\mathrm{Pr}_{\mathrm{l}}+\mathrm{F}_{\mathrm{m}}+\left(\mathrm{Pr}^{*} \mathrm{~F}\right)_{\mathrm{lm}}+\mathrm{e}_{\mathrm{ijklm}}$ where $\mu$ overall mean, $\mathrm{P}_{\mathrm{i}}=$ period effect; $\mathrm{Q}_{\mathrm{j}}=$ square effect; $A_{k}=$ animal effect; $\operatorname{Pr}_{1}=$ cactus processing effect, $\mathrm{F}_{\mathrm{m}}=$ feeding strategy effect, $(\mathrm{Pr} * \mathrm{~F})_{\mathrm{lm}}=$ interaction cactus processing $*$ feeding strategy; $\mathrm{e}_{\mathrm{ijklm}}=$ experimental error.

The data were submitted to analysis of variance (ANOVA) using the SAEG 9.1 statistical analysis package (UFV, 2007). Level of significance of the effects was set at $5 \%$.

\section{Results e Discussion}

There was no significant effect among interactions $(\mathrm{P}>0.05)$ and between the cactus processing and the feeding strategy on any of the studied variables. Thus, the factors were analyzed and discussed separately.

The average daily intake of DM, OM, NDF and TDN were lower $(\mathrm{P}<0.01)$ when the cactus was knife chopped (Table 2), but CP intake and nutrient digestibility were similar $(\mathrm{P}>0.05)$ between both types of cactus processing.

The lower intake of dry matter (kg/day) when the cactus was knife chopped, probably occurred because of the selectivity of the animals, which firstly consumed the cactus, since this ingredient is highly palatable (Nefzaoui \& Ben Salem, 2001; Ben Salem, 2002), mainly due to its high contents of soluble carbohydrate (Table 1 ). Later, the animals consumed a diet higher in bagasse, which was obtained by extraction of sugars and fermentation (in the storage process), originating a product with lower acceptability, rich in cell wall with high contents of NDF (Table 1). In addition, cactus does not expose its mucilage when it is chopped by knife, making the adherence to the bagasse difficult, which may minimize the selectivity.

According to Sniffen \& Robinson (1984), cited in NRC (2001), when ingredients are consumed in a sequence, fiber food must be firstly provided and only after, food rich in soluble carbohydrates is given because when food rich in rapidly fermentable carbohydrates is given first, it may contribute to the appearance of disorders in the ruminal environment, causing a reduction in the consumption. When fibrous foods are given first, there is a stimulus to increase salivation as a result of the chewing process, helping to maintain a ruminal $\mathrm{pH}$ conducive for better 
Table 2 - Intake and digestibility of nutrients in lactating cows under different feeding strategies

\begin{tabular}{|c|c|c|c|c|c|c|c|c|}
\hline & \multicolumn{2}{|c|}{ Cactus processing (proc) } & \multicolumn{2}{|c|}{ Feeding strategy (strat) } & \multirow[t]{2}{*}{ SEM } & \multicolumn{3}{|c|}{$\mathrm{P}$} \\
\hline & $\begin{array}{c}\text { Knife } \\
\text { chopped }\end{array}$ & $\begin{array}{l}\text { Forage } \\
\text { machine }\end{array}$ & $\begin{array}{c}\text { Separate } \\
\text { concentrate }\end{array}$ & $\begin{array}{l}\text { Total mixed } \\
\text { ration }\end{array}$ & & $\begin{array}{c}\text { Cactus } \\
\text { processing }\end{array}$ & Strat & $\begin{array}{l}\text { Processing } \times \\
\text { feed strategy }\end{array}$ \\
\hline \multicolumn{9}{|l|}{ Dry matter } \\
\hline Intake (kg/day) & 15.2 & 16.3 & 15.5 & 16.0 & 0.440 & 0.01 & ns & ns \\
\hline Intake (\% LW) & 3.5 & 3.6 & 3.5 & 3.6 & 0.094 & ns & ns & ns \\
\hline Digestible (g/ kg DM) & 657 & 680 & 667 & 668 & 1.070 & ns & ns & ns \\
\hline \multicolumn{9}{|l|}{ Organic matter } \\
\hline Intake (kg/day) & 13.9 & 14.9 & 14.1 & 14.7 & 0.410 & 0.009 & ns & ns \\
\hline Digestible (g/kg DM) & 679 & 698 & 689 & 689 & 0.990 & ns & ns & ns \\
\hline \multicolumn{9}{|l|}{ Crude protein } \\
\hline Intake (kg/day) & 2.01 & 2.09 & 2.12 & 1.98 & 0.053 & ns & 0.02 & ns \\
\hline Digestible (g/kg DM) & 758 & 779 & 770 & 766 & 0.900 & ns & ns & ns \\
\hline \multicolumn{9}{|l|}{ Neutral detergent fiber } \\
\hline Intake (kg/day) & 6.1 & 6.7 & 6.1 & 6.6 & 0.210 & 0.008 & 0.03 & ns \\
\hline Intake (\% LW) & 1.4 & 1.5 & 1.4 & 1.5 & 0.040 & 0.05 & 0.05 & ns \\
\hline Digestible (g/kg DM) & 419 & 457 & 440 & 436 & 1.935 & ns & ns & ns \\
\hline \multicolumn{9}{|l|}{ Total digestible nutrients } \\
\hline Intake (kg/day) & 9.6 & 10.6 & 9.8 & 10.3 & 0.446 & 0.01 & ns & ns \\
\hline
\end{tabular}

utilization of food. Generally, however, fiber food is less preferred, mainly when the animal has the possibility of choosing some more palatable and digestible foods. According to Ferreira (2005), the way in which cactus is processed deserves attention since when it is processed in appropriate forage machine, mucilage is exposed, allowing the cactus adherence and blending with less palatable diet components, which does not occur when cactus is knife chopped.

Intake of OM, NDF and TDN (kg/day) followed the DM intake behavior for the different types of cactus processing.

Cactus processing had no influence on the DM, OM, $\mathrm{CP}$ and NDF digestibility coefficients. Due to the minimal intake of DM showed by knife chopped cactus, it could be expected a higher digestibility, because reduction on DM intake increases digestibility (López et al., 2001; Long et al., 2004). However, the consumption of low NDF content foods by ruminants reduces the time available for ruminal microbiota to perform digestion due to the increase in the passage rate of digesta in the rumen (Balch \& Campling, 1962; Owens \& Goetsch, 1986; Bondi, 1987; Chen et al., 1992).

The different feeding strategies showed no differences on average daily intake of DM, OM and TDN and nutrient digestibility values $(\mathrm{P}>0.05)$. On the other hand, when the diet was supplied in the total mixed ration way, CP intake (1.98 kg/day, $\mathrm{P}=0.02)$ was lower, whereas NDF intake was higher $(\mathrm{P}=0.03)$. These results can be explained by the increased opportunity of diet selection for separate concentrate feeding strategy, from which animals consumed first the soybean meal, the resource that provided about
$80 \%$ of diet CP, and rejected the bagasse (Table 3), ingredient with low CP and high NDF contents (Table 1).

However, these results differ from those described by Pessoa et al. (2004), who found no differences in nutrient intake $(\mathrm{P}>0.05)$, for total mixed ration and separate concentrate feeding strategies. It should be highlighted that the component used in the study of Pessoa et al. (2004) was sorghum silage, which has greater palatability, and $30 \%$ of the diet was concentrate, whereas in the present study, the concentrate represented only $18.8 \%$ of the diet, being exclusively soybean meal. According to Pessoa et al. (2004) there was an imbalance between the supplied and the consumed diet in the treatment with separate ingredients. The feeding strategy based on TMR prevents, among other factors, food selection, and consequently excessive consumption of any ingredient in the diet (Van Soest, 1994; Nocek, 1997; NRC, 2001; Ingvarsten et al., 2001; Silva et al., 2005) a fact which was not observed in this study, where it was verified effect of selectivity in the proportion of nutrients effectively consumed in relation to the nutrients in the offered diet, even in the form of total mixed ration supply.

According to visual observation of the behavior of the animals as well as to the data (Table 3), it was possible to verify that when the diet was supplied in separate concentrate way, the animals consumed the most palatable components first (cactus and soybean meal) and left the bagasse as scrap.

These results corroborate with those obtained by Maekawa et al. (2002), who observed that cows fed with separate ingredients could select food changingthe forage:concentrate ratio of the original diet from 50:50 to 
close to 40:60. Furthermore, the cows had lower ruminal $\mathrm{pH}$ than those fed total mixed ration. Thus, one advantage of the total mixed ration feeding strategy seems to be a capability of preventing low ruminal $\mathrm{pH}$ associated to increase of concentrate intake.

Feeding strategy also had no influence on digestibility coefficients of dry matter, organic matter, crude protein and neutral detergent fiber. According to Van Soest (1994), several factors can alter digestibility, such as fermentation time and passage rate, which are strongly influenced by the type of diet and proportion of its ingredients. Moreover, NRC (2001) assumes a digestibility reduction when food intake increases. However, it was not observed any effect on food intake in food supply strategies, which may have contributed to the results found in the digestion.

Different ways of processing cactus had no effect ( $\mathrm{P}>0.05$ ) on milk, protein and fat production (kg/day), whose average values were $14.7 ; 0.49$ and $0.54 \mathrm{~kg} /$ day, respectively. The manner in which cactus was processed did not influence $(\mathrm{P}>0.05)$ milk CP content $(\mathrm{g} / \mathrm{kg})$ either. However, the animals which consumed knife-chopped cactus produced milk with lower fat content ( $36 \mathrm{vs} 39 \mathrm{~g} / \mathrm{kg}, \mathrm{P}=0.01$ ) (Table 4).

Although knife-chopped cactus processing provided less DM intake, milk, protein and fat productions (kg/day) were not altered. According to the NRC (2001), requirements of DM, CP and TDN requirements were estimated in 14.6; 1.6 and $7.92 \mathrm{~kg} /$ day, respectively, for milk production of $14 \mathrm{~kg} /$ day of milk with $4 \%$ of fat. All the treatments met the requirements (Table 2). However, there was lower milk fat content ( $/ \mathrm{kg}$ ) when cactus was processed by knife, and that was probably observed due to the differences in ruminal environment and volatile fatty acids concentrations in the rumen caused by selectivity, causing differences in the forage:concentrate ratio in the diet, influencing milk fat content (Sutton, 1989; Gaynor et al., 1995; Nocek, 1997; Kennelly et al., 1999; Ingvarsten et al., 2001). Bispo et al. (2007) observed that increasing the proportion of cactus in the diet for sheep, it caused a linear decrease in rumen $\mathrm{pH}$ from 6.46 to 6.24. According to Batista et al. (2003), 59.5\% of the carbohydrate in cactus is fast and moderate degradability and only $4.4 \%$ are unavailable. The cactus still has $12.9 \%$ starch, which is a relatively high value for forage in general. According to Bispo et al. (2007), this high percentage of rapid carbohydrate digestion is likely to increase microbial activity and concentration of volatile fatty acids, resulting in a decrease in $\mathrm{pH}$. Another aspect to consider is that the mucilage contained in the cactus leads to production of frothy bloat and, consequently, it may reduce the absorption of volatile fatty acids, resulting in a reduction of $\mathrm{pH}$.

R. Bras. Zootec., v.39, n.12, p.2744-2752, 2010 
Table 4 - Performance of lactating cows under different feeding strategies and cactus processing methods

\begin{tabular}{|c|c|c|c|c|c|c|c|c|}
\hline \multirow[t]{2}{*}{ Item } & \multicolumn{2}{|c|}{ Cactus processing } & \multicolumn{2}{|c|}{ Feeding strategy } & \multirow[t]{2}{*}{ SEM } & \multicolumn{3}{|c|}{$\mathrm{P}$} \\
\hline & $\begin{array}{c}\text { Knife } \\
\text { chopped }\end{array}$ & $\begin{array}{l}\text { Forage } \\
\text { machine }\end{array}$ & $\begin{array}{c}\text { Separate } \\
\text { concentrate }\end{array}$ & $\begin{array}{l}\text { Total mixed } \\
\text { ration }\end{array}$ & & Processing & Strategy & $\begin{array}{c}\text { Processing } \times \text { feeding } \\
\text { strategy }\end{array}$ \\
\hline \multicolumn{9}{|l|}{ Yield (kg/day) } \\
\hline Milk & 14.8 & 14.6 & 14.8 & 14.5 & 0.482 & ns & ns & ns \\
\hline $4 \%$ fat corrected milk & 13.8 & 14.2 & 14.3 & 13.7 & 0.374 & ns & ns & ns \\
\hline Protein & 0.48 & 0.50 & 0.50 & 0.49 & 0.014 & ns & ns & ns \\
\hline Fat & 0.52 & 0.56 & 0.56 & 0.52 & 0.015 & ns & ns & ns \\
\hline \multicolumn{9}{|l|}{ Composition (g/kg) } \\
\hline Protein & 34 & 35 & 34 & 34 & 0.050 & ns & ns & ns \\
\hline Fat & 36 & 39 & 38 & 37 & 0.102 & 0.01 & ns & ns \\
\hline
\end{tabular}

Fat corrected milk $=(0.4 \times \mathrm{kg}$ milk $)+(15 \times \mathrm{kg}$ fat $)(\mathrm{NRC}, 2001)$.

For feeding strategies, there were no effect $(\mathrm{P}>0.05)$ on the performance from any of the variables (Table 4). Average values for milk, protein and fat yield were 14.7, 0.49 and $0.54 \mathrm{~kg} /$ day, respectively. These data are inn accordance to Davenport et al. (1983) and Nocek et al. (1986), who found no significant differences in milk production when comparing the effect of total mixed ration and separate concentrate feeding strategies on the performance of dairy cows. Silva et al. (2005) assessing different feeding strategies with cactus-based diets for Holstein cows, found no differences between total mixed rations and separate concentrate feeding strategies on milk production and composition.

However, Pessoa et al. (2004) assessed different feeding strategies with cactus-based diets for Holstein cows and found no differences on milk production among feeding strategies; however, milk fat percentage was influenced by feeding strategy, being lower in treatment in which feed was offered in the separate ingredient way. On the other hand, Ingvartsen et al. (2001) compared the effect of TMR and separate ingredients (forage and concentrate) on milk production and composition, and observed higher milk production in animals fed total mixed ration diets, as for milk fat and protein percentages.

Feeding strategy and cactus processing had no effect $(\mathrm{P}>0.05)$ on microbial protein production and urea excretion (Table 5).
Several factors, such as $\mathrm{N}$ and carbohydrates content and source in diet; feeding frequency; food consumption; forage:concentrate ratio; mineral contents in diet affect microbial protein synthesis in the rumen in such a way that microbial growth is maximized through synchronization between fermentable energy availability and degradable $\mathrm{N}$ in the rumen (Russell et al., 1992; NRC, 1996), have been dealed by many authors (Stern \& Hoover, 1979; Sniffen \& Robinson, 1987; Durand \& Komisarczuk, 1988). The average found in the present study (98.9 $\mathrm{g} \mathrm{MP} / \mathrm{kg}$ of TDN) was similar for cactus processing ways and feeding strategies of the diet, respectively, which is below the value recommended by NRC (2001), which is $130 \mathrm{~g}$ of MP/kg of NDT. In studies carried out in Brazil, Valadares Filho et al. (2006) found efficient values of microbial protein synthesis ranging from 83.1 to 197.9 , with an average value of $119.9 \mathrm{~g} \mathrm{MP} / \mathrm{kg}$ of TDN for lactating cows.

There was no effect on the different cactus processing ways and feeding strategies for $\mathrm{N}$-urea in plasma and milk (Table 5). According to Kohn (2007), several researches have explored the relationship between milk urea-N (MUN) or plasma urea-N (PUN) and protein and energy in consumed diet (Roseler et al., 1993). Variations of MUN and PUN can be obtained by changes in protein:energy ratio. Their concentrations are little affected by $\mathrm{N}$ intake when protein:energy ratio is constant, but they increase when the

Table 5 - Excretion of urea $\mathrm{N}$ in milk and plasma and microbial production

\begin{tabular}{|c|c|c|c|c|c|c|c|c|}
\hline \multirow[t]{2}{*}{ Item } & \multicolumn{2}{|c|}{ Cactus processing } & \multicolumn{2}{|c|}{ Feeding strategy } & \multirow[t]{2}{*}{ SEM } & \multicolumn{3}{|c|}{$\mathrm{P}$} \\
\hline & $\begin{array}{l}\text { Knife } \\
\text { chopped }\end{array}$ & $\begin{array}{l}\text { Forage } \\
\text { machine }\end{array}$ & $\begin{array}{c}\text { Separate } \\
\text { concentrate }\end{array}$ & $\begin{array}{l}\text { Total mixed } \\
\text { ration }\end{array}$ & & Processing & Strategy & $\begin{array}{c}\text { Processing } \times \text { feeding } \\
\text { strategy }\end{array}$ \\
\hline \multicolumn{9}{|l|}{ Excretion of urea } \\
\hline $\mathrm{PUN}^{1}$ (mg/dL) & 20.9 & 21.7 & 21.6 & 21.1 & 1.409 & ns & ns & ns \\
\hline $\mathrm{MUN}^{1}(\mathrm{mg} / \mathrm{dL})$ & 17.7 & 18.6 & 17.5 & 18.9 & 0.457 & ns & ns & ns \\
\hline \multicolumn{9}{|l|}{ Microbial production } \\
\hline Purine derivative (g/day) & 1012.6 & 1013.1 & 944.0 & 1081.7 & 45.235 & ns & ns & ns \\
\hline Microbial protein (g/kg TDN) & 102.5 & 95.4 & 93.1 & 104.7 & 5.168 & ns & ns & ns \\
\hline
\end{tabular}

${ }^{1}$ PUN plasma urea-N; MUN, milk urea-N. 
proportion increases. In the present experiment, the provided diet was isoproteic and isoenergetic. However, the intake of nutrients differed among feeding strategies and cactus processing ways because of selectivity by the animals (Table 3), causing variation in CP:TDN ratio from 0.19 to 0.22.

According to Roseler et al. (1993) and Jonker et al. (2002), MUN concentration has been widely used as an indirect measure for identifying use and efficiency of nitrogen, once this parameter is highly correlated $(r=0.88)$ to PUN. In the present study, MUN and PUN means were 21.1 and $18.5 \mathrm{mg} / \mathrm{dL}$, respectively. A strong correlation ( $r=0.85$ ) was found between these two characteristics. These values corroborate with literature reports on the similarity of these concentrations.

\section{Conclusion}

The two techniques for cactus processing (machine vs knife) have effect on intake of nutrients and fat milk content, but they are similar for milk production. Cactus processed by machine can optimize its use in large amounts, and improve its incorporation in the diet, maximizing dry matter intake. Feeding strategy in the form of total mixed ration (TMR) allows animal selectivity, but with less imbalance between the offered and the consumed diets.

\section{References}

AGRICULTURAL RESEARCH COUNCIL - ARC. The nutrient requirements of ruminants livestock. London: Commonwealth Agricultural Bureaux. 1980. 351p.

BALCH, C.C.; CAMPLING, R.C. Regulation of voluntary food intake in ruminants. Nutrition Abstracts and Reviews, v.32, n.7, p.669-686, 1962.

BATISTA, A.M.V.; MUSTAFA, A.F.; McAllister, T. et al. Effects of variety on chemical composition, in situ nutrient disappearance and in vitro gas production of spineless cacti. Journal of the Science of Food and Agriculture, v.83, n.5, p.440-445, 2003.

BEN SALEM, H.; NEFZAOUI, A.; BEN SALEM, L. Supplementing spineless cactus (Opuntia ficus-indica f. inermis) based diets with urea-treated straw or oldman saltbush (Atriplex nummularia). Effects on intake, digestion and sheep growth. The Journal Agricultural Science, v.138, n.1, p.85-92, 2002.

BISPO, S.V.; FERREIRA, M.A., VÉRAS, A.S.C. et al. Palma forrageira em substituição ao feno de capim-elefante. Efeito sobre consumo, digestibilidade e características de fermentação ruminal em ovinos. Revista Brasileira de Zootecnia, v.36, n.6, p.1902-1909, 2007.

BONDI, A.A. Animal nutrition. London: John Wiley, 1987. 540p.

CHEN, X.B.; GOMES, M.J. Estimation of microbial protein supply to sheep and cattle based on urinary excretion of purine derivatives - An overview of technical details. In: International feed research unit. Aberdeen: Rowett Research Institute, 1992. p.21. (Occasional publication).

CHEN, X.B.; GRUBIC, G.; ØRSKOV, E.R., et al. Effect of feeding frequency on diurnal variation in plasma and urinary purine derivatives in steers. Animal Production, v.55, n.2, 185-191, 1992.

DAVENPORT, D.G.; RAKES, A.H.; McDANIEL, B.T. Group-fed concentrate-silage blend versus individually-fed concentrates and group fed silage for lactating dairy cows. Journal Dairy Science, v.66, n.10, p.2116-2123, 1983.

DUBEUX JR, J.C.B.; SANTOS, M.V.F; LIRA, M.A., et al. Productivity of Opuntia ficus-indica (L.) Miller under different $\mathrm{N}$ and $\mathrm{P}$ fertilization and plant population in north-east Brazil. Journal of Arid Environments, v.67, n.3, p.357-372, 2006.

DURAND, M.; KOMISARCZUK, S. Influence of major minerals on rumen microbiota. The Journal of Nutrition, v.118, n.2, p.249-260, 1988.

FERREIRA, M.A. Palma forrageira na alimentação de bovinos leiteiros. Recife: UFRPE, 2005. 68p.

FUNDAÇÃO DE INFORMAÇÕES PARA O DESENVOLVIMENTO DE PERNAMBUCO - FIDEPE. São Bento do Una; Recife: 1982. 80f. (Monografias Municipais).

GAYNOR, P.J.; WALDO, D.R.; CAPUCO, A.V. et al. Milk fat depression, the glucogenic theory, and Trans-C18:1 fatty acids. Journal of Dairy Science, v.78, n.9, p.2008-2015, 1995.

INGVARTSEN, K.L.; RAKES, A.H.; McDANIEL, B.T. Effects of pattern of concentrate allocation in the dry period and early lactation on feed intake and lactational performance in dairy cows. Livestock Production Science, 71, n.2-3, p.207-221, 2001.

JONKER, J.S.; KOHN, R.A.; HIGHT, J. Use of milk urea nitrogen to improve dairy cow diets. Journal of Dairy Science, v.85, n.4, p.939-946, 2002.

KENNELLY, J.J.; ROBINSON, B.; KHORASANI, G.R. Influence of carbohydrate source and buffer on rumen fermentation characteristics, milk yield, and milk composition in earlylactation Holstein cows. Journal of Dairy Science, v.82, n.11, p.2486-2496, 1999.

KOHN, R. [2007]. Use of milk or blood urea nitrogen to identify feed management inefficiencies and estimate nitrogen excretion by dairy cattle and other animals. Disponível em: <http://dairy.ifas.ufl.edu/files/rns/2007/Kohn.pdf> Acesso em: 16/12/2008.

LONG, R.J.; DONG, S.K.; HU, Z.Z. et al. Digestibility, nutrient balance and urinary purine derivative excretion in dry yak cows fed oat hay at different levels of intake. Livestock Production Science, v.88, n.1-2, p.27-32, 2004.

LÓPEZ, S.; FRUTOS, P.; MANTECÓN, A.R. et al. Comparative digestion of herbage by two breeds of sheep: effects of grass maturity stage and level of intake. Animal Science, v.73, n.3, p.513-522, 2001.

MAEKAWA, M.; BEAUCHEMIN, K. A.; CHRISTENSEN, D.A. Effect of concentrate level and feeding management on chewing activities, saliva production, ruminal $\mathrm{pH}$ of lactating dairy cows. Journal of Dairy Science, v.85, n.5, p.1176-1182, 2002.

NATIONAL RESEARCH COUNCIL - NRC. Nutrient requirements of beef cattle. 7.ed. Washington, D.C.: National Academy Press, 1996. 242p

NATIONAL RESEARCH COUNCIL - NRC. Nutrient requeriments of the dairy cattle. 7.ed. Washigton: D.C.: National Academy Press, 2001. 381p.

NEFZAOUI, A.; BEN SALEM, H. Opuntia spp.: a strategic fodder and efficient tool to combat desertification in the WANA region. In: MONDRAGÓN-JACOBO, C.; PÉREZ-GONZÁLEZ, S. (Eds.). Cactus (Opuntia spp.) as forage. Rome: Food and Agriculture Organization of the United Nations, 2001. p.73-90 (FAO Plant production and protection paper, 169).

NOBEL, P.S. Ecophysiology of Opuntia ficus-indica. In: MONDRAGÓN-JACOBO, C.; PÉREZ-GONZÁLEZ, S. (Eds.) Cactus (Opuntia spp.) as forage. Rome: Food and Agriculture Organization of the United Nations, 2001. p.13-20. (FAO Plant production and protection paper, 169). 
NOCEK, J.E. Bovine acidosis: implications on laminitis. Journal of Dairy Science, v.80, n.5, p.1005-1028, 1997.

NOCEK, J.E.; STEELE, R.L.; BRAUND, D.G. Effect of mixed ration nutrient density on milk of cows transferred from high production group. Journal of Dairy Science, v.68, n.1, p.133139, 1986.

OWENS, F.N.; GOETSCH, A.L. Digesta passage and microbial protein synthesis. In: INTERNATIONAL SYMPOSIUM ON RUMINANT PHYSIOLOGY, 6., 1984, Banff (Canada) Proceedings... Englewood Cliffs, 1986. p.196-223.

PESSOA, R.A.S.; FERREIRA, M.A.; LIMA, L.E. et al. Respuesta de vacas lecheras sometidas a diferentes estratégias de alimentación. Archivos Zootecnia, v.53, n.203, p.309-320, 2004.

ROSELER, D.K.; FERGUNSON, J.D.; SNIFFEN, C.J. et al. Dietary protein degradability effects on plasma and milk urea nitrogen and milk nonprotein nitrogen in Holstein. Journal of Dairy Science, v.76, n.3, p.525-534, 1993.

RUSSELL, J.B.; O’CONNOR, J.D.; FOX, D.J. et al. A net carbohydrate and protein system for evaluating cattle diets: I. Ruminal fermentation. Journal of Animal Science, v.70, n.11, p.3551-3561, 1992

SALIBA, E.O.S. Mini course on the use of indicators. In: TELECONFERÊNCIA SOBRE INDICADORES EM NUTRIÇÃO ANIMAL, 1., 2005, Belo Horizonte. Anais... Belo Horizonte: EV - UFMG, 2005. p.23-26.

SILVA, A.E.V.N.; GUIM, A.; FERREIRA, M.A. et al. Estratégia alimentar para dieta baseada em palma forrageira sobre o desempenho e digestibilidade em vacas em final de lactação. Acta Scientiarum.Animal Sciences, v.27, n.2, p.269-276, 2005.

SILVA, D.J.; QUEIROZ, A.C. Análise de alimentos: métodos químicos e biológicos. 3.ed. Viçosa, MG: UFV, 2002. 235p.

SNIFFEN, C.J.; O'CONNOR, J.D.; VAN SOEST, P.J. et al. A net carbohydrate and protein availability. Journal of Animal Science, v.70, n.11, p.3562-3577, 1992.

SNIFFEN, C.J.; ROBINSON, P.H. Nutritional strategy. Canadian Journal of Animal Science, v.64, p.529-542, 1984.
SNIFFEN, C.J.; ROBINSON, P.H. Microbial growth and flow as influenced by dietary manipulations. Journal of Dairy Science, v.70, n.2, p.425-441, 1987.

STERN, M.D.; HOOVER, W.H. Methods for determining and factors affecting rumen microbial protein synthesis: a review. Journal of Animal Science, v.49, n.6, p.1590-1603, 1979.

SUTTON, D.D. Altering milk composition by feeding. Journal of Dairy Science, v.72, n.10, p.2801-2814, 1989.

UNIVERSIDADE FEDERAL DE VIÇOSA - UFV. Sistema de Análises Estatísticas e Genéticas - SAEG. Versão 9.1. Viçosa, MG, 2007. 150p.

VALADARES FILHO, S.C.; PAULINO, P.V.R.; MAGALHÃES, K.A. Exigências nutricionais de zebuínos de composição de alimentos BR-Corte. Viçosa, MG: UFV-DZO, 2006. $142 \mathrm{p}$.

VALADARES, R.F.D.; BRODERICK, G.A.; VALADARES FILHO, S.C. et al. Effect of replacing alfalfa with high moisture corn on ruminal protein synthesis estimated from excretion of total purine derivatives. Journal of Dairy Science, v.82, n.12, p.2686-2696, 1999.

VAN SOEST, P.J. Development of a comprehensive system of feed analyses and its application to forages. Journal of Animal Science, v.26, n.1, p.119-128, 1967.

VAN SOEST, P.J. Nutritional ecology of the ruminants. 2.ed. Ithaca: Cornell University Press, 1994, 476p.

VAN SOEST, P.J.; ROBERTSON, J.B.; LEWIS, B.A. Symposium: carbohydrate methodology, metabolism, and nutritional implications in dairy cattle. Journal of Dairy Science. v.74, n.10, p.3583-3597, 1991.

VERBIC, J.; CHEN, X.B.; MACLEOD, N.A. et al. Excretion of purine derivatives by ruminants. Effect of microbial nucleic acid infusion on purine derivative excretion by steers. The Journal Agricultural Science, v.114, n.3, p.243-248, 1990.

WEISS, W. Energy prediction equations for ruminant. In: CORNELL NUTRITION CONFERENCE FOR FEED MANUfACTURES, 61., 1999, Ithaca. Proceedings... Ithaca: Cornell University, 1999. p.176-185. 